\title{
SRC Gene Mutation
}

National Cancer Institute

\section{Source}

National Cancer Institute. SRC Gene Mutation. NCI Thesaurus. Code C133688.

A change in the nucleotide sequence of the SRC gene. 